\title{
The Role of Principal Leadership in Improving the Quality of Learning: A Qualitative Study
}

\author{
Widati $^{1 *)}$, Yasir Arafat ${ }^{2}$, Dessy Wardiah ${ }^{2}$ \\ ${ }^{1}$ SDN 12 Muara Telang, Banyuasin, South Sumatra, Indonesia \\ ${ }^{2}$ Universitas PGRI Palembang, Palembang, South Sumatra, Indonesia \\ *Corresponding author. E-mail: widatijantara@gmail.com
}

\begin{abstract}
The principal as a leader has a duty to realize the program and also the vision into the learning implementation process. Quality educational institutions can be realized if they are supported by leaders who understand leadership and the quality of learning as well as its quality. This study aims to determine: (1) the role of principal leadership in improving the quality of learning; and (2) factors that support and hinder the quality of learning. This research was conducted at Public Elementary School (Sekolah Dasar Negeri / SDN) 6 Muara Telang, Banyuasin Regency, Indonesia. The results of this study show that the principal has played a very good role as manager and supervisor. This can be seen from the principal in school learning activities, which as a result, the teachers will succeed in achieving the specified competencies. There are programs that have been set by the principal, factors that hinder the quality of learning activities in schools as well as obstacles and solutions for better quality learning in the future.
\end{abstract}

Keywords: Leadership, Principal, Quality of Learning

\section{INTRODUCTION}

Educational institutions play an important role in making quality national education that can compete in this global era. If educational institutions are advanced, Indonesian education will also advance. In educational institutions, of course, the principal name of the school will not be separated. The principal as an actor, priest, leader, stakeholder in the school. The school principal if likened to a mechanical system, the principal is the main motor driving the system. The system will not run when the motor is less than optimal.

If the analogy is in the world of school management, then the progression of schools, whether good or bad, is largely determined by the role of the school principal. So, it is not surprising if there are schools that were originally low in quality, suddenly become schools with superior quality and are in demand by education customers. The principal plays an effective role in mobilizing other school components, to work together in achieving quality improvement and school success.

The first step in any quality learning activity is planning the quality of learning, which is the process of identifying customer needs objectively and accurately as possible. School principal or education leader and functioning education supervisor as supervisor role clearly appears [1]. In managing education, the principal plays a role as a leader, manager, administrator and supervisor, while in learning the principal acts as an educator or learner, because the principal, although managing education, also carries out learning tasks. The principal in improving the quality of learning, needs to pay attention to matters relating to teacher performance, mastery of material, use of teaching methods, utilization of educational tools, organizing learning, and evaluating and implementing curricular activities.

\section{METHODS}

\subsection{Types of research}

This type of research is a descriptive study that aims to systematically and accurately describe the facts and characteristics about the population or about certain fields. This study seeks to describe a situation or event [2]. This research uses a qualitative approach. Research with a qualitative approach emphasizes the analysis of the process of thinking inductively related to the dynamics of the relationship between observed phenomena, and always uses scientific logic. The purpose of qualitative research is to develop the concept of sensitivity to the problem at hand, to explain the reality related to exploring grounded theory and to develop an understanding of one or more of the phenomena at hand.

Qualitative research is a research method used in revealing problems in the work life of government, private, community, youth, sports, arts and culture organizations, so that it can be used as a policy to be implemented for the common welfare [3]. Researchers 
use a qualitative approach, because researchers try to understand the complexity of the phenomenon under study, interpret and then report a phenomenon, and also to understand a phenomenon from the perspective of the actor in it. It is hoped that the understanding of the researcher and the actors will complement each other and be able to explain the complexity of the observed phenomenon [4].

\subsection{Research Subjects and Data}

This research was conducted at SDN 6 Muara Telang, Banyuasin Regency, Indonesia. The research subject was the principal. As for the informants in this study were the principal, and teachers, as well as all sources related to the leadership role of the principal in improving the quality of learning. Sources of research data are the subjects from which data can be obtained. If researchers use interviews in data collection, the data source is called the respondent. Whereas if researchers using observation techniques, the data source can be in the form of objects, motion or something processes. If the researcher uses documentation techniques, then the documents or notes will be the source of the data. There are two sources of data used in this study, namely: (1) primary data sources; and (2) secondary data sources.

Primary data source, in this study primary data is in the form of notes from interviews and direct observations in field obtained through interviews. In this study, primary data sources were obtained from the principal as a leader in the school and an important factor in his task of improving the quality of learning. Secondary data sources are used to support information obtained from primary data sources, namely from library materials, literature, previous research, books, activity reports held by libraries and so on. To obtain secondary data in this study, the researchers collected it from the teachers. This is done so that researchers obtain additional data that has not been obtained from primary data sources.

\subsection{Data analysis}

Data analysis was carried out by using the following steps: (1) data reduction; (2) data presentation; and (3) conclusion drawing / verification. Data reduction, summarizes selecting the main things, focusing on important things related to the leadership of the principal in improving the quality of learning. Presentation of data, the results of the study are presented and described as they are related to the leadership of the principal in improving the quality of learning. Conclusion drawing / verification, making conclusions to answer the problem formulation.

Testing the validity of the data, researchers used triangulation techniques. Triangulation includes: (1) triangulation of sources, carried out using different sources of information; (2) method triangulation, carried out using two or more data collection techniques; and (3) data triangulation, requesting input from informants or asking other researchers to analyze the same data.

\section{RESULTS AND DISCUSSION}

The role of the principal's leadership in realizing the quality of learning is by designing school programs so that they become better and more efficient schools. The school principal acts as a manager to manage the school. This role is a central role in overcoming various problems that exist in schools. The leadership roles of school principals include: (1) the principal as a manager; (2) the principal as administrator; (3) the principal as a supervisor; (4) the principal as the leader; (5) the principal as an innovator; and (6) the principal as a motivator.

The principal's leadership constraints in improving the quality of learning are: (1) lack of educators; and (2) insufficient learning facilities and infrastructure. Another obstacle in improving the quality of learning is the problem of learning aids being damaged, so that learning activities are less effective and innovative. This damage is caused by the absence of a special room to place learning aids. The efforts of the principal in improving the quality of learning are: (1) increasing teacher professionalism; (2) supervise and supervise the learning carried out by educators in the classroom; and (3) provide motivation and guidance to teachers and education personnel.

Solutions in improving the quality of learning are: (1) adding educators; (2) provide infrastructure and facilities for learning; (3) the teacher tries to increase the variety of active learning; (4) conduct comparative studies on other advanced schools based on the good and best quality of learning, in order to create an increase in the quality of learning for schools; (5) trying to bring back teachers from outside the region so that they can teach the experience to the school with the best quality of learning and can improve it to the best quality; and (6) maximizing learning patterns with the best quality in the role of the principal.

From the results of supervision, it can be seen that the weaknesses and strengths of the teacher in implementing learning include the level of mastery of the competence of the teacher concerned, then efforts are made to provide guidance and follow-up solutions so that the teacher can correct deficiencies and maintain their excellence in implementing learning. The role of the principal in improving the quality of education includes: as a manager, administrator, supervisor, leader, innovator, and motivator.

The principal has a significant effect on teacher work and activity participation [5], [6]. The principal has a duty to shape and improve and strive for the quality of learning well so that schools can become the best schools. The principal must have a lot of new ideas [7], [8], such as carrying out self-development and carrying out several study visits to several schools 
that have successfully implemented development [9], [10].

This is done as an effort to make a quality school. The obstacle to the principal's leadership in improving the quality of learning is the limited number of educators [11]-[14]. The principal's effort to improve the quality of learning is to increase teacher professionalism in order to improve the quality of teaching [14]-[19]. And the solution to improving the quality of learning is to add educational staff, and provide infrastructure and facilities for learning.

It can be said that if teachers in a school have been able to implement strategies for improving the quality of learning appropriately [20]-[23], then the results of their education will have superior quality that is able to meet the demands of the global era Then the teacher as the spearhead of educational success is required to have high skills to implement the strategy improving the quality of learning [24][28].

The success of the learning process and the quality of graduates / outputs cannot be separated from the leadership role of the school principal [29][31], because the principal as a person who has the duty and responsibility to lead the school [31], [32], and is responsible for the achievement of educational goals in schools [33], [34]. The principal is expected to be a leader and motivator so that he is able to provide new innovations in developing the implementation of the educational process and the learning process as an effort to educate the nation's life [35]-[37]. Therefore, the leadership of the principal is a very significant element for the success of education in schools.

\section{CONCLUSION}

Based on the results of the study, it is concluded that there is an advantage of the teacher in implementing learning, namely the level of mastery of the competence of the teacher concerned. Coaching and follow-up are carried out so that teachers can correct deficiencies and maintain their excellence in implementing learning. The role of school principals in improving the quality of education includes as managers, administrators, supervisors, leaders, innovators, and motivators.

\section{REFERENCES}

[1] N. Alim, "Manajemen Supervisi Pendidikan". Kendari: Istana Profesional, 2007.

[2] A. Saifuddin, "Metode Penelitian". Yogyakarta: Pustaka Pelajar, 2015.

[3] I. Gunawan, "Metode Penelitian Kualitatif: Teori dan Praktik”. Jakarta: PT Bumi Aksara, 2013.

[4] S. Sarosa, "Penelitian Kualitatif: Dasar-dasar". Jakarta: PT Indeks, 2012.

[5] A. Solikah, "Strategi Peningkatan Mutu Pembelajaran pada Sekolah Unggulan", Retrieved 2 December 2020, from https://jurnal.iainkediri.ac.id.
[6] I. Bafadal, I. Gunawan, and A. Nurabadi, "Leadership in Excellent School: A Qualitative Study". In 1st International Conference on Information Technology and Education (ICITE 2020) (pp. 63-66), Atlantis Press, 2020.

[7] A. Nurabadi, I. Bafadal, I. Gunawan, A. S. I. Burham, and E. J. Bengen, "Website Development for Principals Induction Program". In 2020 6th International Conference on Education and Technology (ICET) (pp. 205208), IEEE, 2020.

[8] D. N. Sari, I. Gunawan, and A. Imron, "Relationship Between Managerial Skills and Morale With Teacher Performance: A Regression Analysis". In 6th International Conference on Education and Technology (ICET 2020) (pp. 125-129), Atlantis Press, 2020.

[9] I. Bafadal, I. Gunawan, and A. Nurabadi, "School Performance Development: Measurement of Variables Affected by the Moral Debate Program". In 6th International Conference on Education and Technology (ICET 2020) (pp. 201-205), Atlantis Press, 2020.

[10] A. D. Wardani, I. Gunawan, D. E. Kusumaningrum, D. D. N. Benty, R. B. Sumarsono, A. Nurabadi, ... \& S. Maulina, "Subject Teacher Deliberation: Role and Functions in School Management". In 1st International Conference on Information Technology and Education (ICITE 2020) (pp. 720-724), Atlantis Press, 2020.

[11] A. D. Wardani, I. Gunawan, D. E. Kusumaningrum, D. D. N. Benty, R. B. Sumarsono, A. Nurabadi, ... \& S. Maulina, "How Teachers Optimize the Role of Classroom Administration in Learning?" In 6th International Conference on Education and Technology (ICET 2020) (pp. 422-426), Atlantis Press, 2020

[12] S. K. Rofiah, I. Gunawan, and A. D. Wardani, "What Multimedia Can Teachers Use in Learning?" In 1st International Conference on Information Technology and Education (ICITE 2020) (pp. 691-695), Atlantis Press, 2020.

[13] C. M. Shanti, I. Gunawan, and A. Y. Sobri, "Relationship of School Visionary Leadership and Organizational Climate with Teacher Performance". In 1st International Conference on Information Technology and Education (ICITE 2020) (pp. 624-629), Atlantis Press, 2020.

[14] A. Prastiawan, I. Gunawan, A. P. Putra, D. A. Dewantoro, P. S. Cholifah, N. L. S. Nuraini, ... \& E. Surahman, "Organizational Climate in School Organizations: A Literature Review". In 1st International Conference on Information Technology and Education (ICITE 2020) (pp. 725-728), Atlantis Press, 2020.

[15] Juharyanto, A. Nurabadi, and I. Gunawan, "Debat Moral Sebagai Upaya Meningkatkan Integritas Kepala Sekolah". JAMP: Jurnal 
Administrasi dan Manajemen Pendidikan, Vol. 3, No. 3, p. 272-282, 2020.

[16] D. E. Kusumaningrum, R. B. Sumarsono, and I. Gunawan, "Pengaruh Kepemimpinan Pembelajaran, Kepemimpinan Perubahan, Kepemimpinan Spiritual, Budaya Sekolah, dan Etika Profesi terhadap Kinerja Mengajar Guru". JMSP (Jurnal Manajemen dan Supervisi Pendidikan), Vol. 4, No. 3, 198-219, 2020.

[17] Sultoni, I. Gunawan, and H. Argadinata, "Dampak Pembelajaran Berkarakter Terhadap Penguatan Karakter Siswa Generasi Milenial”. JAMP: Jurnal Administrasi dan Manajemen Pendidikan, Vo. 3, No. 2, p. 51-61, 2020.

[18] E. M. Budiarti, I. Gunawan, and B. A. Pambudi, "The Effect of Spiritual Leadership and Academic Supervision on Teacher Performance". In 6th International Conference on Education and Technology (ICET 2020) (pp. 157-161), Atlantis Press, 2020.

[19] B. A. Pambudi, and I. Gunawan, "The Effect of Learning Leadership and Academic Supervision on Teacher Teaching Skills in the Covid-19 Pandemic". In 6th International Conference on Education and Technology (ICET 2020) (pp. 15), Atlantis Press, 2020.

[20] N. L. S. Nuraini, P. S. Cholifah, A. P. Putra, E. Surahman, I. Gunawan, D. A. Dewantoro, and A. Prastiawan, "Social Media in the Classroom: A Literature Review". In 6th International Conference on Education and Technology (ICET 2020) (pp. 264-269), Atlantis Press, 2020.

[21] H. Andriningrum, P. S. Cholifah, I. Gunawan, A. S. M. Harisman, A. F. Putri, T. Amelia, ... \& D. A. Wulandari, "Development of Smylings (System for Monitoring Healthy Living Skills) for Health Education in Primary School". In 2020 6th International Conference on Education and Technology (ICET) (pp. 21-25), IEEE, 2020.

[22] N. N. Sukawati, I. Gunawan, A. G. Prayoga, and A. D. Wardani, "Teacher Personality, Interpersonal Relationships, Performance, and Professionalism in the Learning Process: A Qualitative Study". In 6th International Conference on Education and Technology (ICET 2020) (pp. 250-254), Atlantis Press, 2020.

[23] D. Prestiadi, I. Gunawan, and R. B. Sumarsono, "Role of Transformational Leadership in Education 4.0". In 6th International Conference on Education and Technology (ICET 2020) (pp. 120-124), Atlantis Press, 2020.

[24] A. Prastiawan, I. Gunawan, A. P. Putra, D. A. Dewantoro, P. S. Cholifah, N. L. S. Nuraini, ... and E. Surahman, "School Leadership Skills in Educational Institutions. In 6th International Conference on Education and Technology (ICET 2020) (pp. 438-441), Atlantis Press, 2020.

[25] I. Gunawan, I. Bafadal, and A. Nurabadi, "School Leadership Strategy in Excellent Schools". In 6th International Conference on
Education and Technology (ICET 2020) (pp. 210-215), Atlantis Press, 2020.

[26] A. N. Faizah, I. Gunawan, I. Bafadal, and A. Timan, "The Relationship between Learning Leadership and Teacher Performance: A Correlation Analysis". In 1st International Conference on Information Technology and Education (ICITE 2020) (pp. 599-602), Atlantis Press, 2020.

[27] I. Bafadal, I. Gunawan, and A. Nurabadi, "Leadership in Excellent School: A Qualitative Study". In 1st International Conference on Information Technology and Education (ICITE 2020) (pp. 63-66), Atlantis Press, 2020.

[28] D. E. Kusumaningrum, R. B. Sumarsoso, and I. Gunawan, "Budaya Sekolah dan Etika Profesi: Pengukuran Pemberdayaan Sumber Daya Manusia Sekolah dengan Pendekatan Soft System Methodology". JAMP: Jurnal Administrasi dan Manajemen Pendidikan, Vol. 2, No. 3, p. 90-97, 2019.

[29] I, Gunawan, "The Implementation of Lesson Study Based Learning Management and the Effect toward Students' Activeness in Lecturing”. JPP (Jurnal Pendidikan dan Pembelajaran), Vol. 24, No. 2, 51-63, 2018.

[30] I. Gunawan, "Instructional Leadership Profile of Junior High School's Principal (A Case Study of Junior High School in Malang)". International Research-Based Education Journal, Vol. 1, No. 1, 2017.

[31] D. E. Kusumaningrum, R. B. Sumarsono, and I. Gunawan, "Problematika Pemberdayaan dan Pengembangan Sumber Daya Manusia di Sekolah Menengah Pertama Berbasis Pesantren”. Ilmu Pendidikan: Jurnal Kajian Teori dan Praktik Kependidikan, Vol. 2, No. 2, p. 139-150, 2017.

[32] Suminah, I. Gunawan, and S. Murdiyah, "Peningkatan Hasil Belajar dan Motivasi Belajar Siswa melalui Pendekatan Behavior Modification”. Ilmu Pendidikan: Jurnal Kajian Teori dan Praktik Kependidikan, Vol. 3, No. 2, p. 221-230, 2018.

[33] Sultoni, I. Gunawan, and D. N. Sari, "Pengaruh Etika Profesional Terhadap Pembentukan Karakter Mahasiswa”. JAMP: Jurnal Administrasi dan Manajemen Pendidikan, Vol. 1, No. 3, p. 279-283, 2018.

[34] D. E. Kusumaningrum, R. B. Sumarsono, and I. Gunawan, "Professional ethics and teacher teaching performance: Measurement of teacher empowerment with a soft system methodology approach". International Journal of Innovation, Creativity and Change, Vol. 5, No. 4, p. 611-624, 2019.

[35] I. Bafadal, A. Nurabadi, A. Y. Sobri, and I. Gunawan, "The Competence of Beginner Principals as Instructional Leaders in Primary Schools". International Journal of Innovation, 
Creativity and Change, Vol. 5, No. 4, p. 625-639, 2019.

[36] I. Gunawan, D. D. N. Benty, D. E. Kusumaningrum, R. B. Sumarsono, D. N. Sari, F. D. Pratiwi. \& L. K. Hui, "Validitas dan Reliabilitas Angket Keterampilan Manajerial Mahasiswa". JAMP: Jurnal Administrasi dan
Manajemen Pendidikan, Vol. 2, No. 4, p. 247257, 2019.

[37] A. Y. Sobri, I. Bafadal, A. Nurabadi, and I. Gunawan, "Development of Mentoring Modules Based on Self-Reflection for Beginner Principal". In 3rd International Conference on Educational Management and Administration (CoEMA 2018), Atlantis Press, 2018. 